\title{
Seroprevalence and factors associated with hepatitis B virus infection among the hill tribe youths, northern Thailand
}

Tawatchai Apidechkul ${ }^{1,2}$

\begin{abstract}
Background: Hepatitis B virus (HBV) infection is a major viral infection, particularly in people living in the Western Pacific region, including the hill tribe people living in northern Thailand. This study aimed to estimate the prevalence of HBV infection and to detect the factors associated with HBV infection among hill tribe youths in Thailand.
\end{abstract}

Methods: A cross-sectional study was conducted to estimate the prevalence and determine the factors associated with HBV infection among hill tribe youths living in northern Thailand. A validated questionnaire and $5 \mathrm{~mL}$ blood sample were used for data collection. The Wondfo Diagnostic Kit ${ }^{\oplus}$, the Wondfo One Step HBsAg Serum/Plasma Test ${ }^{\oplus}$, and the Wondfo One Step HBsAg Serum/Plasma Test ${ }^{\oplus}$ were used for anti-HBsAg, HBsAg, and total anti-HBc detections, respectively. Logistic regression was used to detect associations between variables with an $\alpha=0.05$ significance level.

Results: A total of 836 participants were included in the study; 62.7\% were female, 58.9\% were aged 15-17 years, 58.7\% were Buddhist, 78.4\% graduated high school, and $89.1 \%$ had no income. The majority were Akha (30.0\%), Yao (16.3\%), and Hmong (15.8\%); 13.2\% smoked, 21.5\% used alcohol, 13.3\% had tattoos, 3.9\% experienced drug injection from illegal practitioners, and $35.7 \%$ had no history of HBV immunization. The prevalence of HBsAg was 3.0\%; anti-HBs, 10.2\%; and total anti-HBC, $8.1 \%$. In the multivariate analysis, four variables were found to be significantly associated with HBV infection among the hill tribe youths: age, tribe, work experience, and number of partners. Those aged 18-20 years and $21-24$ years had 2.13 times $(95 \% \mathrm{Cl}=1.35-3.29)$ and 2.39 times $(95 \% \mathrm{Cl}=1.05-3.90)$ greater odds of HBV infection, respectively, than those aged 15-17 years. Akha, Lahu, and Hmong youths had 3.12 times ( $95 \% \mathrm{Cl}=1.07-9.12)$, 3.71 times $(95 \% \mathrm{Cl}=1.21-11.41)$, and 3.84 times $(95 \% \mathrm{Cl}=1.26-11.69)$ greater odds of HBV infection, respectively, than Lisu youths. Those who had experience working outside of the village had a 1.77 times $(95 \% \mathrm{Cl}=1.18-2.98)$ greater chance of HBV infection than those who did not have experience working outside of the village, and those who had $\geq 2$ partners had a 2.66 times $(95 \% \mathrm{Cl}=1.96-3.87)$ greater chance of HBV infection than those who had no partner.

Conclusions: Effective HBV prevention programs should be promoted in Akha, Lahu, and Hmong youth populations, particularly to those who have sexual partners, work outside of the village and are aged 18-24 years.

Keywords: Hepatitis B, Seroprevalence, Hill tribe, Youths, HBsAg, Anti-HBs, Total anti-HBC

Correspondence: tk2516ms@gmail.com; tawatchai.api@mfu.ac.th

${ }^{1}$ Center of Excellence for the Hill tribe Health Research, Mae Fah Laung

University, 333 Mo.1 Tasud Subdistrict, Muang District, Chiang Rai Province

57100, Thailand

${ }^{2}$ School of Health Science, Mae Fah Luang University, Chiang Rai, Thailand

(c) The Author(s). 2019 Open Access This article is distributed under the terms of the Creative Commons Attribution 4.0 International License (http://creativecommons.org/licenses/by/4.0/), which permits unrestricted use, distribution, and reproduction in any medium, provided you give appropriate credit to the original author(s) and the source, provide a link to the Creative Commons license, and indicate if changes were made. The Creative Commons Public Domain Dedication waiver (http://creativecommons.org/publicdomain/zero/1.0/) applies to the data made available in this article, unless otherwise stated. 


\section{Background}

Hepatitis B infection is an infectious diseases with one of the largest impacts on human health, with approximately 257 million infected people worldwide [1]. The target organ of the infection is the human liver [2]. The infection leads to several health problems, including acute and chronic diseases such as hepatitis, cirrhosis, and hepatocellular carcinoma (HCC), etc. [1]. Approximately $80-90 \%$ of infections occur in the first year of life, and $30-50 \%$ of infections that occur before the age of 6 progress to the chronic stage [3]. The chronic stage of HBV infection eventually leads to the development of HCC during middle age $[4,5]$. HCC is one of the most invasive and aggressive cancers [6]. Moreover, HCC rates impact the national health system and health economics of a country.

According to a World Health Organization (WHO) report, people living in the Western Pacific region are the most vulnerable to $\mathrm{HBV}$ infection [1], with a prevalence rate of $6.2 \%$. Regarding impacted persons, one-third of hepatitis B cases are reported from the Western Pacific region [7]. China has been recognized as one of the countries with the highest HBV burden, with a reported prevalence of $5.58 \%$ [8]. There are several minority populations living in South China [9]. Many of the so-called hill tribe people have been migrating and settling in northern Thailand since the nineteenth century [10]. Today, there are more than three million hill tribe people living in Thailand, which are classified into six main groups: Akha, Lahu, Hmong, Yao, Karen, and Lisu [11]. They have their own culture and lifestyles, including traditional practices that might be related to $\mathrm{HBV}$ infection, such as ear piercing and traditional acupuncture [12, 13]. In 2018, approximately 200,000-300,000 hill tribe people lived in Chiang Rai Province, which is located in the northernmost part of Thailand [11]. Today, the hill tribe people still maintain their own daily lifestyles and traditional practices; however, many villagers, particularly those who are living in Chiang Rai Province, are exposed to several risk factors outside their village through globalization. Chiang Rai Province borders Myanmar in the west, China in the north, and the Republic of Laos in the East.

The hill tribes in Thailand have become vulnerable to HBV infection for various reasons, such as their own traditional practices [11], low socioeconomic status [13], poor access to health care, language barriers [14], distance to health care settings [13], and stigmatization from health care providers [13]. In 2018, there were almost 3.5 million hill tribe people living in Thailand; however, some of them were not registered as Thai citizens [11]. Citizenship allows any individual to obtain a national identification card when they reach the age of 7 under Thai regulation [15]. The ID card is used to access all public services, including health care services and school attendance, free of charge.

Due to their living environment, social context, and socioeconomic status, the hill tribe populations in Thailand are at risk of HBV infection, particularly youths who belong to the third or fourth generations of the hill tribes living in Thailand today. The hill tribe youths are at a stage in their lives where it is very possible to be exposed to people outside their villages during different daily activities. Many hill tribe youths are exposed to people outside their villages due to work or attending school in a large city. Exposure to people and experiences outside the village, including sexual partners, tattoos, alcohol and illegal substances, have made them a new vulnerable population for HBV infection. There is little scientific information available regarding hepatitis B infection among hill tribe youths who are sexually active, eager to explore, and exposed to new experiences outside of their villages. Thus, the study aimed to estimate the prevalence and to determine the factors associated with HBV infection among hill tribe youths in northern Thailand.

\section{Methods}

Study design

A cross-sectional study was performed collect data from hill tribe youths.

\section{Study setting}

The participants were recruited from 60 selected hill tribe villages. Five villages of each tribe were selected by a simple random method from lists of the hill tribe villages located in Chiang Rai Province, northern Thailand. In 2016, there were 749 hill tribe villages in Chiang Rai, which included 316 Lahu villages, 243 Akha villages, 63 Yao villages, 56 Hmong villages, 36 Karen villages, and 35 Lisu villages. In 2016, a total of 41,366 hill tribe families lived in Chiang Rai Province [16].

\section{Study population}

The study population comprised hill tribe youths aged 15-24 years.

\section{Eligible population}

Eligible populations were hill tribe youths from one of the six hill tribes living in Chiang Rai Province.

\section{Inclusion and exclusion criteria}

The inclusion criteria were as follows: a) the participant self-identified as a member of one of the six hill tribes, b) the participant was aged between 15 and 24 years at the date of data collection, and c) the participant was fluent in Thai. However, selected participants who had a physical or mental condition that led to the inability to 
provide essential information regarding the study protocols were excluded from the study.

\section{Sample size}

The sample size was calculated based on a formula for calculating the sample size in a cross-sectional study [17];

$$
\mathrm{n}=\left[\mathrm{Z}^{2}{ }_{\alpha / 2} \mathrm{PQ}\right] / \mathrm{e}^{2}
$$

where $\mathrm{n}=$ sample size required, $\mathrm{Z}=1.96, P=0.10$ [18], $\mathrm{Q}=0.90$ and $\mathrm{e}=0.05$. An average of 138 cases per tribe was required. Based on six tribes, a total of 829 participants were required for the analysis.

\section{Research instruments}

A questionnaire and $5 \mathrm{~mL}$ blood specimens were used as research instruments. A questionnaire was developed from a literature review and consultations with experts in the field. The questionnaire consisted of 31 questions categorized into three sections. In the first section, 10 questions were used to collect general information from the participants, such as sex, age, tribe, and marital status. In the second section, 8 questions were used to collect information on risk behaviors such as smoking, alcohol drinking, tattoos, and ear piercing. In the last section, 13 questions were used to collect information on the sexual behaviors of the participants, such as the number of partners, use of condoms during sexual intercourse, and sexual orientation.

\section{Research instrument development}

The questionnaire was tested for validity by the item-objective congruence technique (IOC), which was performed by three external experts in the relevant fields, a virologist, an infectious disease specialist, and an infectious epidemiologist. Questions with a score of less than 0.50 were excluded from the questionnaire, questions with a score between $0.50-0.70$ were revised before use, and questions with a score of $>0.70$ were used without modification.

Afterward, the questionnaire was piloted on 20 persons (10 males and 10 females) in the Mae Chan district of Chiang Rai Province who were similar to the study participants, with the aim of assessing the reliability and feasibility of the questionnaire.

\section{Process of data gathering}

After identifying all sixty selected hill tribe villages, village headmen were contacted 2 days before data collection. Access to villages was granted by district government officers. The lists of the target subjects were obtained from the village headmen. In each village, all eligible subjects were informed about the research objectives and protocols by the village headman. The study samples were randomly selected from the lists provided. All selected samples were appointed in the village. Upon reaching the village, all selected samples were provided all essential information and written informed consent was obtained before completing the questionnaire. Five milliliter blood samples were voluntarily collected by a professionally licensed medical technologist. Blood samples were kept in a proper container with cold packs and transferred to the laboratory on the same day.

\section{Laboratory method}

Laboratory tests were performed at the Mae Fah Luang Medical Laboratory. A rapid immunochromatographic method was used to detect anti-HBs and HBsAg markers. The Wondfo Diagnostic Kit ${ }^{\circledR}$ was used to detect ant-HBsAg with $97.3 \%$ sensitivity and $99.2 \%$ specificity. The Wondfo One Step HBsAg Serum/Plasma Test $^{\circ}$ was used to detect HBsAg with $96.2 \%$ sensitivity and $99.3 \%$ specificity. For the anti-HBc, the Wondfo One Step HBsAg Serum/Plasma Test ${ }^{\circ}$ was used with $93.0 \%$ sensitivity and $99.0 \%$ specificity.

\section{Laboratory interpretation}

Participants who were negative for HBsAg, total anti-HBc, and anti-HBs were susceptible to HBV infection. Participants who were negative for both $\mathrm{HBsAg}$ and total anti-HBc but positive for anti-HBs were defined as having immunity due to hepatitis $B$ vaccination. Participants who were negative for HBsAg but positive for total anti-HBc and anti-HBs were defined as having immunity due to natural infection. HBV infection was defined as people who were positive for $\mathrm{HBsAg}$ and/or total anti-HBc after excluding individuals who had a serological profile of previous vaccination against $\mathrm{HBV}[19,20]$.

\section{Statistical analysis}

All questionnaires and laboratory information were coded and double entered into an Excel sheet. Data were checked for errors, including missing values, before analysis. Data were analyzed by SPSS version 24, 2016 (SPSS, Chicago, IL). Descriptive and inferential statistics were used for analysis; general characteristics of participants were described by means, standard deviations, and percentages. Logistic regression was used to detect the associations between independent variables (general characteristics, risk behaviors, and sexual behaviors) and the dependent variable, HBV infection, at the $\alpha=0.05$ significance level. The "ENTER" method was chosen in the logistic regression model, and statistically nonsignificant variables were excluded from the model; therefore, only statistically significant variables were included in the interpretation. 


\section{Results}

A total of 836 participants were recruited for the study, and nobody refused to participate. The majority of participants were females aged $15-17$ years (mean $=17.5, \mathrm{SD}=2.4$ ) and of the Akha tribe. Most participants were single, in school, had no income, and had 4-6 family members. Half of the participants were Buddhist (Table 1).

Regarding the risk behaviors, different kinds of drug use were detected among the participants: 13.2\% smoked, $21.5 \%$ drank alcohol, $2.3 \%$ used methamphetamines, and 4.3\% used marijuana. Two-thirds experienced ear piercing, and $13.3 \%$ were tattooed. Some participants reported blood transfusions (3.9\%), organ transplants $(1.0 \%)$, a history of drug injection from illegal practitioners (3.9\%), and acupuncture (1.8\%). Only $8.5 \%$ were immunized for HBV, and $2.9 \%$ had at least one family member who had hepatitis. One-third of the participants reported that they had a sexual experience, $44.9 \%$ did not use a condom during their first sexual intercourse, and $11.5 \%$ had $\geq 2$ partners (Table 2).

The prevalence rate of $\mathrm{HBsAg}$ positivity was $3.0 \%$, anti-HBs positivity was $10.2 \%$, total anti-HBc positivity was $8.1 \%$, and both anti-HBs and anti-HBc positivity was $0.92 \%$. The rate of negativity for anti-HBs but positivity for total anti-HBc was $7.4 \%$. The prevalence rate of HBV infection was $10.3 \%$ (Table 3 ).

In the univariate analysis, five variables were associated with HBV infection among the hill tribe youths: age, tribe, marital status, work experience outside the village, and number of sexual partners. However, in the multivariate analysis, four variables remained associated with HBV infection. Those aged 18-20 years and $21-24$ years had 2.13 times $(95 \% \mathrm{CI}=1.35-3.29)$ and 2.39 times $(95 \% \mathrm{CI}=1.05-3.90)$ greater odds of $\mathrm{HBV}$ infection, respectively, than those aged 15-17 years. Akha, Lahu, and Hmong youths had 3.12 times $(95 \% \mathrm{CI}=1.07-9.12), 3.71$ times $(95 \% \mathrm{CI}=1.21-11.41)$, and 3.84 times $(95 \% \mathrm{CI}=1.26-11.69)$ greater odds of HBV infection, respectively, than Lisu youths. Those who had experience working outside the village had a 1.77 times $(95 \% \mathrm{CI}=1.18-2.98)$ greater chance of $\mathrm{HBV}$ infection than those who did not work outside the village, and those who had $\geq 2$ sexual partners had a 2.66 times $(95 \% \mathrm{CI}=1.96-3.87)$ greater chance of HBV infection than those who did not have a sexual partner (Table 4).

\section{Discussion}

In this study, the prevalence of HBsAg was $3.0 \%$, the prevalence of anti-HBV was $10.2 \%$, and the prevalence of HBV infection was $10.3 \%$. The hill tribe youths in Thailand who were of the Akha, Lahu, and Hmong tribes; were older; had more than one partner; and had
Table 1 General characteristics of the participants

\begin{tabular}{|c|c|}
\hline Characteristics & n (\%) \\
\hline$\overline{\text { Total }}$ & $836(100.0 \%)$ \\
\hline \multicolumn{2}{|l|}{ Sex } \\
\hline Male & $312(37.3)$ \\
\hline Female & $524(62.7)$ \\
\hline \multicolumn{2}{|l|}{ Age (years) } \\
\hline $15-17$ & $492(58.9)$ \\
\hline $18-20$ & $248(29.7)$ \\
\hline $21-24$ & $96(11.5)$ \\
\hline \multicolumn{2}{|l|}{ Tribe } \\
\hline Akha & $251(30.0)$ \\
\hline Lahu & $110(13.2)$ \\
\hline Hmong & $132(15.8)$ \\
\hline Yao & $136(16.3)$ \\
\hline Karen & $130(15.5)$ \\
\hline Lisu & $77(9.2)$ \\
\hline \multicolumn{2}{|l|}{ Marital status } \\
\hline Single & $791(94.6)$ \\
\hline Other & $45(5.4)$ \\
\hline \multicolumn{2}{|c|}{ Family members (persons) } \\
\hline$\leq 3$ & $92(11.0)$ \\
\hline $4-6$ & $529(63.3)$ \\
\hline $7-10$ & $181(21.7)$ \\
\hline$\geq 11$ & $34(4.1)$ \\
\hline \multicolumn{2}{|l|}{ Religion } \\
\hline Buddhism & $491(58.7)$ \\
\hline Christianity & $339(40.6)$ \\
\hline Islam & $6(0.7)$ \\
\hline \multicolumn{2}{|l|}{ Education } \\
\hline Illiterate & $21(2.5)$ \\
\hline Primary school & $31(3.7)$ \\
\hline High school & $655(78.4)$ \\
\hline Vocational school & $129(15.4)$ \\
\hline \multicolumn{2}{|l|}{ Occupation } \\
\hline Unemployed & $62(7.4)$ \\
\hline Student & $685(81.9)$ \\
\hline Farmer & $22(2.6)$ \\
\hline Laborer & $67(8.1)$ \\
\hline \multicolumn{2}{|l|}{ Income } \\
\hline No & $745(89.1)$ \\
\hline Yes & $91(10.9)$ \\
\hline \multicolumn{2}{|l|}{ Living place } \\
\hline Own house & $590(70.6)$ \\
\hline Dormitory & $208(24.9)$ \\
\hline Other & $38(4.5)$ \\
\hline
\end{tabular}


Table 2 Risk behaviors among the participants

\begin{tabular}{|c|c|c|}
\hline Characteristics & $\mathrm{n}$ & $\%$ \\
\hline \multicolumn{3}{|l|}{ Smoker } \\
\hline No & 726 & 86.8 \\
\hline Yes & 110 & 13.2 \\
\hline \multicolumn{3}{|l|}{ Alcohol use } \\
\hline No & 656 & 78.5 \\
\hline Yes & 180 & 21.5 \\
\hline \multicolumn{3}{|c|}{ Methamphetamine us } \\
\hline No & 817 & 97.7 \\
\hline Yes & 19 & 2.3 \\
\hline \multicolumn{3}{|l|}{ Heroin use } \\
\hline No & 823 & 98.4 \\
\hline Yes & 13 & 1.6 \\
\hline \multicolumn{3}{|c|}{ Crystal methamphetamine use } \\
\hline No & 825 & 98.7 \\
\hline Yes & 11 & 1.3 \\
\hline \multicolumn{3}{|l|}{ Opium use } \\
\hline No & 824 & 98.6 \\
\hline Yes & 12 & 1.4 \\
\hline \multicolumn{3}{|l|}{ Marijuana use } \\
\hline No & 800 & 95.7 \\
\hline Yes & 36 & 4.3 \\
\hline \multicolumn{3}{|l|}{ Tattooed } \\
\hline No & 725 & 86.7 \\
\hline Yes & 111 & 13.3 \\
\hline \multicolumn{3}{|l|}{ Ear piercing } \\
\hline No & 302 & 36.1 \\
\hline Yes & 534 & 63.9 \\
\hline \multicolumn{3}{|c|}{ History of blood transfusion } \\
\hline No & 803 & 96.1 \\
\hline Yes & 33 & 3.9 \\
\hline \multicolumn{3}{|c|}{ History of organ transplant } \\
\hline No & 828 & 99.0 \\
\hline Yes & 8 & 1.0 \\
\hline \multicolumn{3}{|c|}{ History of medical surgery } \\
\hline No & 733 & 87.7 \\
\hline Yes & 103 & 12.3 \\
\hline \multicolumn{3}{|c|}{ Injection from illegal practitioners } \\
\hline No & 803 & 96.1 \\
\hline Yes & 33 & 3.9 \\
\hline \multicolumn{3}{|l|}{ Acupuncture } \\
\hline No & 821 & 98.2 \\
\hline Yes & 15 & 1.8 \\
\hline \multicolumn{3}{|c|}{ Work experience outside the village } \\
\hline No & 693 & 82.9 \\
\hline
\end{tabular}

Table 2 Risk behaviors among the participants (Continued)

\begin{tabular}{|c|c|c|}
\hline Characteristics & $n$ & $\%$ \\
\hline Yes & 143 & 17.1 \\
\hline \multicolumn{3}{|c|}{ Work experience abroad } \\
\hline No & 826 & 98.8 \\
\hline Yes & 10 & 1.2 \\
\hline \multicolumn{3}{|c|}{ Used a shared toothbrush } \\
\hline No & 656 & 78.5 \\
\hline Yes & 180 & 21.5 \\
\hline \multicolumn{3}{|c|}{ History of hepatitis B vaccination } \\
\hline Yes & 71 & 8.5 \\
\hline No & 298 & 35.7 \\
\hline Not sure & 261 & 31.2 \\
\hline Unknown & 206 & 24.6 \\
\hline \multicolumn{3}{|c|}{ Family member history of hepatitis } \\
\hline No & 481 & 57.5 \\
\hline Yes & 24 & 2.9 \\
\hline Not sure & 120 & 14.4 \\
\hline Unknown & 211 & 25.2 \\
\hline \multicolumn{3}{|l|}{ Sexual experience } \\
\hline No & 593 & 70.9 \\
\hline Yes & 243 & 29.1 \\
\hline \multicolumn{3}{|c|}{ Used a condom during first sexual intercourse } \\
\hline No & 109 & 44.9 \\
\hline Yes & 120 & 49.4 \\
\hline Unremembered & 14 & 5.7 \\
\hline \multicolumn{3}{|c|}{ Number of partners (persons) } \\
\hline None & 593 & 70.9 \\
\hline 1 & 147 & 17.6 \\
\hline$\geq 2$ & 96 & 11.5 \\
\hline
\end{tabular}

experienced working outside the village had a higher risk of HBV infection.

Thailand has included the HBV vaccine in their expanded program of immunization (EPI) since 1992 [21-23]. All children are immunized with at least three doses of the HBV vaccine, with the first dose given $24 \mathrm{~h}$ after birth. In 2017, after 25 years of HBV vaccination through the EPI program, a 99.0\% HBV vaccine coverage was reported for the whole country [22]. However, in our study, only 71 out of 836 participants $(8.5 \%)$ confirmed having received HBV vaccination; $31.2 \%$ reported that they were not sure if they had been immunized, and $24.6 \%$ reported that they did not know their HBV immunization status. However, there were only 3 cases positive for $\mathrm{HBsAg}$ and 3 cases positive for anti-HBs among those who had a history of HBV immunization. These data differ from the 90-95\% efficacy rate of the HBV vaccine after 3 standard doses declared by the 
Table 3 Prevalence of HBsAg and anti-HBs

\begin{tabular}{|c|c|c|}
\hline Characteristics & $\mathrm{n}$ & $\%$ \\
\hline Total & 836 & 100.0 \\
\hline \multicolumn{3}{|l|}{$\mathrm{HBsAg}$} \\
\hline Negative & 811 & 97.0 \\
\hline Positive & 25 & 3.0 \\
\hline Received HBV vaccination & 3 & 12.0 \\
\hline No history of HBV vaccination & 6 & 24.0 \\
\hline Not sure & 9 & 36.0 \\
\hline Unknown & 7 & 28.0 \\
\hline \multicolumn{3}{|l|}{ Anti-HBs } \\
\hline Negative & 751 & 89.8 \\
\hline Positive & 85 & 10.2 \\
\hline Received HBV vaccination & 3 & 3.5 \\
\hline No history of HBV vaccination & 32 & 37.6 \\
\hline Not sure & 31 & 36.5 \\
\hline Unknown & 19 & 22.4 \\
\hline \multicolumn{3}{|l|}{ Total anti-HBC } \\
\hline Negative & 768 & 91.9 \\
\hline Positive & 68 & 8.1 \\
\hline Received HBV vaccination & 0 & 0.0 \\
\hline No history of HBV vaccination & 12 & 17.6 \\
\hline Not sure & 27 & 39.8 \\
\hline Unknown & 29 & 42.6 \\
\hline Anti-HBs-positive and anti-HBc-positive & 4 & 0.9 \\
\hline Anti-HBs-negative and anti-HBc-positive & 64 & 7.4 \\
\hline HBV infection & 86 & 10.3 \\
\hline
\end{tabular}

Ministry of Public Health in Thailand [24]. This reflects the level of access to health care services among the hill tribe people in Thailand, which was reportedly low due to factors such as distance, language and stigmatization $[14,25]$. There are also many factors influencing the efficacy of HBV immunization, such as nutritional status [26], route of vaccine delivery [27], age at vaccination, underlying diseases [28, 29], and host genetics [30]. Moreover, with low parental education rates and low health literacy, including the administration of the HBV immunization in children while they are young, may have led to missing responses to question in the study which might impact the analysis. During the data collection, many sources of information were investigated regarding the HBV immunization status of a participant. A study conducted at the Thai-Myanmar border reported that administering HBV vaccines to people living in the border area was highly effective in preventing the disease [31].

Regarding HBsAg seroprevalence, countries in the Western Pacific region had a rate of 6.1\% [1]. In Taiwan, the seroprevalence of anti-HBsAg and total anti-HBc was $8.1 \%$ and increased according to age, particularly in those aged 18-25 years [32]. In 2015, Leroi et al. [17] reported that the overall seroprevalence of HBsAg in the Thai general population was $0.6-3.1 \%$. Lana, et al. [21] reported that the HBs-carrier rate of Thai people aged 11-20 was $0.69 \%$. These findings are lower than the seroprevalence detected in our study among hill tribe youths in Thailand.

Moreover, Banks, et al. [33] reported that the hepatitis B seroprevalence among pregnant women who lived on the Thailand-Myanmar border was $8.3 \%$. Another study that was conducted with children and adolescents with HIV infection in six countries in Southeast Asia, including Thailand, reported that the prevalence of HBsAg was 4.7\% [34]. Pichainarong, et al. [35] reported that the hepatitis B seroprevalence among married hill tribe women in northern Thailand was $8.2 \%$. These studies presented HBsAg seroprevalence rates close to the rates in our study due to similar population demographics. Another reason might be an increase in the number of people who are exposed to people outside their village (17.1\%). Today, many hill tribe people prefer to work outside of their village to earn money to support their family [36]. In fact, hill tribe people, particularly those aged below 25 years, should have low HBsAg since they were born after the implementation of HBV vaccination in Thailand. Another reason for high anti-HBsAg and anti-HBc levels among hill tribe people is due to low seroclearance, particularly in those who were infected at an older age [37, 38].

Regarding age and HBV infection, Taleban et al. [39] reported that increased age was one of the most significant factors for HBV infection in Iran. A study among health care professionals in Ethiopia in 2017 also reported that people who were older in age had a significantly greater risk of HBV infection than those younger in age [40]. Another study conducted among prisoners in Iran reported that age was the significant factor associated with HBV infection [41]. These findings support our study, which found that the older age group had a greater risk of HBV infection among the hill tribe youths in northern Thailand, even though they were born after the national implementation of HBV vaccination in Thailand.

Slovakia reported that some group of people had a greater risk than others; the Roma population had a greater risk of HBV infection than both the non-Roma population and those with tattoos [42]. Our study also found that some tribes had a greater risk of HBV infection than others.

The number of partners was highly associated with HBV infection in pregnant women in Ethiopia [43] and Tanzania [44]. A study among female workers in Laos also reported that the number of partners was associated with 
Table 4 Univariate and multivariate analyses of factors associated with HBV infection

\begin{tabular}{|c|c|c|c|c|c|c|c|c|}
\hline Factors & $n$ & $\%$ & OR & $95 \% \mathrm{Cl}$ & $p$-value & $\mathrm{OR}_{\text {Adj }}$ & $95 \% \mathrm{Cl}$ & $p$-value \\
\hline \multicolumn{9}{|l|}{ Sex } \\
\hline Male & 312 & 37.3 & 1 & & & & & \\
\hline Female & 524 & 62.7 & 0.70 & $0.47-1.06$ & 0.707 & & & \\
\hline \multicolumn{9}{|l|}{ Age (years) } \\
\hline $15-17$ & 492 & 58.9 & 1 & & & 1 & & \\
\hline $18-20$ & 248 & 29.7 & 2.14 & $1.38-3.34$ & $0.001^{a}$ & 2.13 & $1.35-3.29$ & $0.001^{a}$ \\
\hline $21-24$ & 96 & 11.4 & 2.39 & $1.33-4.30$ & $0.004^{\mathrm{a}}$ & 2.39 & $1.05-3.90$ & $0.005^{\mathrm{a}}$ \\
\hline \multicolumn{9}{|l|}{ Tribe } \\
\hline Akha & 251 & 30.0 & 3.05 & $1.05-8.87$ & $0.040^{a}$ & 3.12 & $1.07-9.12$ & $0.037^{\mathrm{a}}$ \\
\hline Lahu & 110 & 13.2 & 4.30 & $1.41-13.10$ & $0.010^{a}$ & 3.71 & $1.21-11.41$ & $0.022^{a}$ \\
\hline Hmong & 132 & 15.8 & 3.65 & $1.20-11.02$ & $0.022^{\mathrm{a}}$ & 3.84 & $1.26-11.69$ & $0.018^{a}$ \\
\hline Yao & 136 & 16.3 & 2.09 & $0.66-6.60$ & 0.207. & 2.46 & $0.77-7.87$ & 0.127 \\
\hline Karen & 130 & 15.5 & 2.02 & $0.63-6.45$ & 0.232 & 1.86 & $0.58-5.98$ & 0.293 \\
\hline Lisu & 77 & 9.2 & 1 & & & 1 & & \\
\hline
\end{tabular}

Marital status

$\begin{array}{llllll}\text { Single } & 791 & 94.6 & 1 & & \\ \text { Other } & 45 & 5.4 & 2.26 & 1.11-4.60 & 0.025^{\text {a }}\end{array}$

Number of family members (persons)

1-3

4-6

7-10

$\geq 11$

Religion

Buddhism

Islam

Education

Illiterate

Primary school

High school

Vocational school

Occupation

Unemployed

Student

Farmer

Labor

Income

No
Yes

Smoker

No
Yes

Yes

Alcohol use
No

656
$0.67-2.92$

0.361

0.65-3.31

0.343

$0.64-6.04$

0.233

$0.53-1.24$

0.345

$0.14-10.62$

0.855

$0.51-14.90 \quad 0.235$

$0.31-5.94 \quad 0.651$

$0.35-7.62 \quad 0.527$

$\begin{array}{ll}0.39-1.75 & 0.632 \\ 0.68-7.14 & 0.186 \\ 0.39-2.73 & 0.948\end{array}$

0.948

0.52-1.90 0.993 
Table 4 Univariate and multivariate analyses of factors associated with HBV infection (Continued)

\begin{tabular}{|c|c|c|c|c|c|c|c|c|}
\hline Factors & $n$ & $\%$ & OR & $95 \% \mathrm{Cl}$ & $p$-value & $\mathrm{OR}_{\text {Adj }}$ & $95 \% \mathrm{Cl}$ & $\overline{p \text {-value }}$ \\
\hline Yes & 180 & 21.5 & 1.36 & $0.86-2.16$ & 0.187 & & & \\
\hline \multicolumn{9}{|c|}{ Methamphetamine use } \\
\hline No & 817 & 97.7 & 1 & & & & & \\
\hline Yes & 19 & 2.3 & 1.24 & $0.35-4.34$ & 0.732 & & & \\
\hline \multicolumn{9}{|c|}{ Heroin use } \\
\hline No & 823 & 98.4 & 1 & & & & & \\
\hline Yes & 13 & 1.6 & 1.20 & $0.26-5.50$ & 0.811 & & & \\
\hline \multicolumn{9}{|c|}{ Crystal methamphetamine use } \\
\hline No & 825 & 98.7 & 1 & & & & & \\
\hline Yes & 11 & 1.3 & 0.65 & $0.08-5.18$ & 0.690 & & & \\
\hline
\end{tabular}

Tattooed

$\begin{array}{llllll}\text { No } & 725 & 86.7 & 1 & & \\ \text { Yes } & 111 & 13.3 & 1.13 & 0.63-2.00 & 0.674\end{array}$

Ear piercing

$\begin{array}{llllll}\text { No } & 302 & 36.1 & 1 & & \\ \text { Yes } & 534 & 63.9 & 0.94 & 0.62-1.43 & 0.788\end{array}$

History of blood transfusion

$\begin{array}{llllll}\text { No } & 803 & 96.1 & 1 & & \\ \text { Yes } & 33 & 3.9 & 0.65 & 0.19-2.16 & 0.484\end{array}$

History of medical surgery

$\begin{array}{llll}733 & 87.7 & 1\end{array}$

Yes 103

$12.3 \quad 1.04$

$0.57-1.90$

0.889

Injection from illegal practitioners

$\begin{array}{llllll}\text { No } & 803 & 96.1 & 1 & & \\ \text { Yes } & 33 & 3.9 & 0.65 & 0.19-2.16 & 0.484\end{array}$

Acupuncture

$\begin{array}{llllll}\text { No } & 821 & 98.2 & 1 & & \\ \text { Yes } & 15 & 1.8 & 1.01 & 0.22-4.56 & 0.984\end{array}$

Used a shared toothbrush

$\begin{array}{llllll}\text { No } & 656 & 78.5 & 1 & & \\ \text { Yes } & 180 & 21.5 & 1.02 & 0.62-1.65 & 0.937\end{array}$

History of hepatitis B vaccination

$\begin{array}{llllll}\text { Yes } & 71 & 8.5 & 1 & & \\ \text { No } & 298 & 35.7 & 1.58 & 0.64-3.90 & 0.319 \\ \text { Not sure } & 261 & 31.2 & 1.96 & 0.79-4.83 & 0.143 \\ \text { Unknown } & 206 & 24.6 & 1.56 & 0.61-3.97 & 0.346\end{array}$

Family history of hepatitis

$\begin{array}{llllll}\text { No } & 481 & 57.5 & 1 & & \\ \text { Yes } & 24 & 2.9 & 0.58 & 0.13-2.53 & 0.471 \\ \text { Not sure } & 120 & 14.4 & 1.05 & 0.59-1.87 & 0.852 \\ \text { Unknown } & 211 & 25.2 & 0.89 & 0.55-1.46 & 0.670\end{array}$

Work experience outside the village

No 693

Yes

143

$82.9 \quad 1$

$1.20-3.07 \quad 0.006^{\mathrm{a}}$

1.77

$1.18-2.98$

$0.004^{\mathrm{a}}$ 
Table 4 Univariate and multivariate analyses of factors associated with HBV infection (Continued)

\begin{tabular}{|c|c|c|c|c|c|c|c|c|}
\hline Factors & $\mathrm{n}$ & $\%$ & OR & $95 \% \mathrm{Cl}$ & $p$-value & $\mathrm{OR}_{\text {Adj }}$ & $95 \% \mathrm{Cl}$ & p-value \\
\hline \multicolumn{9}{|l|}{ Work experience abroad } \\
\hline No & 826 & 98.8 & 1 & & & & & \\
\hline Yes & 10 & 1.2 & 2.88 & $0.73-11.30$ & 0.130 & & & \\
\hline \multicolumn{9}{|l|}{ Sexual experience } \\
\hline Yes & 243 & 29.1 & 1.10 & $0.71-1.71$ & 0.648 & & & \\
\hline No & 593 & 70.9 & 1 & & & & & \\
\hline \multicolumn{9}{|c|}{ Used a condom during first sexual intercourse } \\
\hline Yes & 120 & 49.4 & 1 & & & & & \\
\hline No & 109 & 44.9 & 1.49 & $0.70-3.17$ & 0.293 & & & \\
\hline Does not remember & 14 & 5.7 & 1.26 & $0.25-6.23$ & 0.775 & & & \\
\hline \multicolumn{9}{|c|}{ Number of sexual partners (person) } \\
\hline None & 593 & 84.7 & 1 & & & 1 & & \\
\hline 1 & 67 & 9.6 & 0.43 & $0.15-1.22$ & 0.113 & 0.57 & $0.28-1.19$ & 0.099 \\
\hline$\geq 2$ & 40 & 5.7 & 2.97 & $1.90-4.30$ & $0.033^{\mathrm{a}}$ & 2.66 & $1.96-3.87$ & $0.047^{a}$ \\
\hline
\end{tabular}

a Significant at $a=0.05$

HBV infection [45]. Another study in Bangkok reported that the number of partners was associated with HBV infection [46]. These findings are similar to our study, which found that the number of partners was significantly associated with HBV infection among hill tribe youths, particularly those who had experience working outside of the village. Some studies $[47,48]$ conducted in hill tribe people in Thailand reported that working outside of the village was a factor associated with HIV and hepatitis B coinfection in northern Thailand.

Marital status was found to be associated with HBV infection in the univariate model; however, there was no statistical association with HBV infection in the multivariate model. A possible reason is for this result may be that many hill tribes have a monogamous culture, except the Akha who accept polygamy in their culture [25]. Those who have multiple partners often do so before marriage; once they are married, the opportunity for HBV infection is reduced. Several studies have also shown that marital status is not associated with HBV infection $[49,50]$.

Recall bias and misclassification were major limitations in the study. Recall bias [51, 52] happened since many questions regarding previous experiences were asked. For instance, a large proportion answered "not sure" or "unknown" when asked about their history of hepatitis B vaccination. These answers may have led to misclassification during analysis. However, the researchers were aware of these issues and repeated the questions during the interview to ensure the participants understood the questions before providing their answers.

All the HBsAg-positive participants were provided recommendations to seek further medical investigation, proper care and treatment. Those who were not immune were provided additional information regarding immunization at a registered hospital to protect against HBV infection.

\section{Conclusion}

The hill tribe youths in Thailand are at risk of hepatitis B infection, particularly those who work outside the village and have multiple sexual partners. Due to globalization, young children in the hill tribes should be immunized with the HBV vaccine through the EPI program of Thailand to ensure that they are immune to HBV infection. Moreover, suitable health education programs, such as safe sex practices, should be developed and implemented in Akha, Lahu, and Hmong youth populations aged $\geq 18$ years.

\section{Abbreviations}

Anti-HBc: Hepatitis core antibody; Anti-HBs: Hepatitis B surface antibody; $\mathrm{Cl}$ : Confident interval; EPI: Expanded program of immunization; HBsAg: Hepatitis B surface antigen; HBV: Hepatitis B virus; HCC: Hepatocellular carcinoma; IOC: Item-objective congruence technique; MSM: Men who have sex with men; WHO: World Health Organization

\section{Acknowledgements}

The author would like to thank all the participants for kindly providing essential information. I also would like to thank the National Research Council of Thailand Mae Fah Luang University, and the Center of Excellence for the Hill tribe Health Research for grant support. Finally, we would like to express our special thank to colleagues from WHO-Thailand for technical support.

\section{Funding}

TA received funding from The National Research Council of Thailand and Mae Fah Luang University (Grant No. 60207020106).

The funders had no role in the design of the study and collection, analysis, and interpretation of data and in writing the manuscript.

Availability of data and materials

Additional data could request at email: Tawatchai.api@mfu.ac.th 


\section{Authors' contributions}

TA planned and conducted the project, collected data, analyzed, drafted and proofread the final version of the manuscript. The author read and approved the final manuscript.

\section{Authors' information}

Dr. Tawatchai Apidechkul is the Assistant Professor and Director of the Center of Excellence for the Hill-tribe Health Research and trained in infectious disease epidemiology at Emory University in the United States under the Hubert $\mathrm{H}$. Humphrey (Fulbright) program and in the Global Health Delivery Intensive Program from Harvard University.

\section{Ethics approval and consent to participate}

All the research protocols and procedures were approved by the Mae Fah Luang University Research Ethics Committee on Human Research (REH-60001). All participants were asked to obtain the inform consent before asking to provide information, collect blood specimen and starting the data collection process. Those participants aged less than 18 years, parents were asked to sign the informed consent form on behalf of the participants before starting the data collection process

\section{Consent for publication}

Not applicable.

\section{Competing interests}

The authors declare that they have no competing interests.

\section{Publisher's Note}

Springer Nature remains neutral with regard to jurisdictional claims in published maps and institutional affiliations.

\section{Received: 26 November 2018 Accepted: 28 January 2019} Published online: 06 February 2019

\section{References}

1. World Health Organization (WHO). Hepatitis B: Key facts. http://www.who. int/news-room/fact-sheets/detail/hepatitis-b

2. World Health Organization (WHO). Guidelines on hepatitis B and C testing http://www.who.int/hepatitis/publications/hepatitis-b-guidelines/en/.

3. Centers for Disease Control and Prevention. Viral hepatitis B. https:/www. cdc.gov/hepatitis/hbv/index.htm

4. Kao WY, Su CW, Tan EC, Lee PC, Chen PH, Tang JH, et al. Proton pump inhibitors and risk of hepatocellular carcinoma in patients with chronic hepatitis B or C. Hepatology. 2018. https://doi.org/10.1002/hep.30247.

5. Choi J, Kim GA, Han S, Lee W, Chun S, Lim YS. Longitudinal assessment of three serum biomarkers to detect very early stage hepatocellular carcinoma. Hepatology. 2018. https://doi.org/10.1002/hep.30233.

6. Lisa PW, Vrushak D, Nikolaos P. Hepatocellular carcinoma: A comprehensive review. World J Hepatol. 2015;7(26):2648-63.

7. World Health Organization (WHO). Global hepatitis report 2017. http://apps. who.int/iris/bitstream/handle/10665/255016/9789241565455-eng.pdf; jsessionid $=699 \mathrm{D} 49 \mathrm{FD} 849542 \mathrm{~F} 6768 \mathrm{BBDEC} 9279 \mathrm{E} 810$ ? sequence $=18$.

8. Xu C, Chen T. Global prevalence of hepatitis B virus infection and prevention of mother-to-child transmission. Lancet Gastroenterol Hepatol. 2018;3(9):598-9.

9. Gao X, Wang X, Zhu B. The distribution of Chinese minority populations and its change based on the study of the Hu Huanyong line. Int J Anthropol Ethnol. 2017;1(2). https://doi.org/10.1186/s41257-017-0004-9.

10. Princess Maha Chakri Siridhorn Anthropology center. Hill tribe. 2018. http:// www.sac.or.th/main/index.php

11. Lukas H. Southeast Asian hill tribes and the opium trade - The historical and social-economic background of the marginalization of minorities using the example of Thailand. Austria: University of Vienna. p. 2017.

12. Apidechkul T. A 20-year retrospective cohort study of TB infection among the hill tribe HIV/AIDS populations, Thailand. BMC Infectious Disease. 2016; 16:72. https://doi.org/10.1186/s12879-016-1407-4.

13. Apidechkul T, Jiamton $S$, Jareinpituk $S$, Kaewkungwal J. Sexual behaviors and HIV infection among pregnant hill tribe women in northern Thailand. Southeast Asian J Trop Med Public Health. 2007;38(6):1061-9.
14. Apidechkul $\mathrm{T}$, Laingoen $\mathrm{O}$, Suwannaporn $\mathrm{S}$. Inequity in accessing health care service in Thailand in 2015: a case study of the hill tribe people in Mae Fah Luang district, Chiang Rai, Thailand. J Health Res. 2016;30(1):67-71.

15. Department of Provincial Administration, Ministry of Interior, Thailand. Act on the card 2011. http://www.moi.go.th/portal/page?_pageid= 814,1036627,814_1036665\&_dad=portal\&_schema= PORTAL.

16. The hill tribe welfare and development center, Chiang Rai province. Hill tribe population. The hill tribe welfare and development center. Chiang Rai: Ministry of Interior; 2016. p. 13-21.

17. Peter B, Leslie EW, Mark RS, Charles EM. Ethic and sample size. Am J Epidemiol. 2005;161(2):105-10.

18. Leroi C, Adam P, Khamduang W, Kawilapat S, Neo-Giang-Huong, Ongwandee $S$, et al. Prevalence of chronic hepatitis B virus infection in Thailand: a systematic review and meta-analysis. In J Infect Dis 2016; 51: $136-43$.

19. Trepo C, Chan HL, Lok A. Hepatitis B virus infection. Lancet. 2014;384(9959): 2053-63.

20. Centers for Disease Control and Prevention (CDC). Interpretation of hepatitis B serologic test results. 2018. http://www.cdc.gov/hepatitis/hbv/pdfs/ serologicchartv8.pdf.

21. Lana C, Sigrun R, Rania AT. Status and progress of hepatitis B control through vaccination in the South-East Asia Region, 2992-2015. Vaccine. 2018;36(1):6-14.

22. World Health organization (WHO). EPI Fact Sheet: Thailand. http://www. searo.who.int/immunization/data/thailand.pdf

23. Posuwan N, Wanlapakorn N, Sa-Nguanmoo P, Wasitthakasem R, Vichaiwattana P, Klimfueng S, et al. The success of a universal hepatitis B immunization program as part of Thailand's EPI after 22 years' implementation. PLoS One. 2016;11(3):e0150499. https://doi.org/10.1371/ journal.pone.0150499.

24. Ministry of Public Health, Thailand. Efficacy and effectiveness of hepatitis B vaccine among Thai children. https://ddc.moph.go.th/th/site/index

25. Apidechkul T, Wongnuch P, Sithisarn S, Ruanjai T. Health status of Akha hill tribe in Chiang Rai province, Thailand. J Pub Health Dev. 2016;14(1):77-97.

26. Scott DP, Inna GO, Gregory AP. The weight of obesity on the human immune response to vaccine. Vaccine. 2015:33(36):4422-9.

27. Anja S, Beate K. Vaccine responses in newborns. Semin Immunopathol. 2017;39(6):627-42

28. Teresa A, Jane B, John RB, Bonnie BB, Wilbur HC, Julian H, et al. Report on WHO meeting on immunization in older adults: Geneva, Switzerland, 22-23 march 2017. Vaccine. 2018;36(7):921-31.

29. Pham TT, Le HM, Nguyen DT, Maertens K, Leuridan E, Theeten $H$, et al. Assessment of the timely administration of the hepatitis B and BCG birth dose and the primary infant vaccination schedule in 2015-2016 in the Mekong Delta, Vietnam. Vaccine. 2018;36(38):5760-5.

30. Akcay IM, Katrinli S, Ozdil K, Doganay GD, Doggany L. Host genetic factors affecting hepatitis B infection outcomes: insights from genome-wide association studies. World J Gastroenterol. 2018;24(30):3347-60.

31. Angela D, Rebecca H, Aung MN, Mary EG, Moo KP, Joy K, et al. Strategies for the prevention of perinatal hepatitis $B$ transmission in a marginalized population on the Thailand-Myanmar border: a cost-effectiveness analysis. BMC Infect Dis. 2017;17:552. https://doi.org/10.1186/s12879-017-2660-x.

32. Lai MW, Lin TY, Tsao KC, Huang CG, Hsiao MJ, Liang KH, et al. Increased seroprevalence of HBV DNA with mutations in the $\mathrm{S}$ gene among individuals greater than 18 years old after complete vaccination. Gastroenterology. 2012;143(2):400-7.

33. Banks T, Kang J, Watts I, Tyrosvoutis ME, Min AM, Tun NW, et al. High hepatitis B seroprevalence and risk factors for infection in pregnant women on the Thailand-Myanmar border. J Infect Dev Ctries. 2016;10(4):384-8.

34. Aurpibul L, Kariminia A, Vibol U, Fong MS, Le ON, Hansudewechakul R, et al. Seroprevalence of hepatitis B among HIV-infected children and adolescents receiving antiretroviral therapy in the TREAT Asia pediatric HIV observational database. Pediatr Infect Dis J. 2018;37(8):788-93.

35. Pichainarong N, Chaveepojnkamjorn W, Luksamijarulkul P, Sujirarat D, Apidechkul T. Hepatitis B carrier among married hill tribe women in northern Thailand. Southeast Asian J Trop Med Public Health. 2003;34(1): 114-9.

36. Apidechkul T. Prevalence and factors associated with type 2diabetes mellitus and hypertension among the hill tribe elderly populations in northern Thailand. BMC Public Health. 2018;18:694. https://doi.org/10.1186/ s12889-018-5607-2. 
37. Teerapat U, Tassanee S, Pattama K, Pitchayachuda C, Kamonwan S, Gaidganok S, et al. Role of quantitative hepatitis B surface antigen in predicting inactive carriers and $\mathrm{HBSAg}$ seroclearance in $\mathrm{HBeAg}$-negative chronic hepatitis B patients. Medicine (Baltimore). 2017;96(13):e6554

38. Catherine MN, John SL. Natural history of chronic hepatitis B: phases in a complex relationship. World J Gastroenterol. 2014;20(30):10395-404.

39. Teleban R, Moafi M, Ataei B, Yaran M, Nokhodian Z, Kassaian N, et al. Seroprevalence of hepatitis B infection and associated risk factors among drug users in drop-in centers of Isfahan, Iran. Int J Prev Med. 2018;9(46) DOI: 10.4103 .

40. Demsiss W, Seil A, Fiseha T. Hepatitis B and C: seroprevalence, knowledge, practice and associated factors among medicine and health science students in Northeast Ethiopia. PLoS One. 2018;13(5):e0196539.

41. Moradi G, Gouya MM, Azimizan ZF, Mohamadi BA, Darvishi S, Aghasadeghi $\mathrm{MR}$, et al. Prevalence and risk factors for HBV and HCV in prisoners in Iran; a national bio-behavioral surveillance survey in 2015. Tropical Med Int Health. 2018;23(6):641-9.

42. Drazilova S, Janicko M, Kristian P, Schreter I, Halanova M, Urbancikova I, et al. Prevalence and risk factors of hepatitis $B$ virus infection in Roma and nonRoma people in Slovakia. Int J Environ Res Public Health. 2018;15(5). https:// doi.org/10.2290/ijerph15051047.

43. Amsalu A, Ferede G, Eshetie S, Tadewos A, Assegu D. Prevalence, infectivity, and associated risk factors on hepatitis B virus among pregnant women in Yirgalem hospital, Ethiopia: implication of screening to control mother-to-child transmission. J Pregnancy. 2018:8435910. https://doi.org/ 10.1155/2018/8435910.

44. Kapinga D, Aboud S. Seroprevalence and factors associated with hepatitis B virus infection in pregnant women attending antenatal clinic in Karagwe district council, Tanzania. Int J Infect Dis. 2018;73(Supp):369.

45. Xaydalasouk K, Strobel M, Buisson Y, Black AP, Muller CP. Seroprevalence and risk factors of hepatitis $B$ and $C$ virus infections in female workers of Lao garment factories. PLoS One. 2018;13(7):e0199919.

46. Linkins RW, Chonwattana W, Holtz TH, Wasinrapee P, Chaikummao S, Varangrat $A$, et al. Hepatitis A and hepatitis B infection prevalence and associated risk factors in men who have sex with men, Bangkok, 2006-2008. J Med Virol. 2013;85(9):1499-505.

47. Apidechkul T, Pongwiriyakul S. Factors associated with HIV and HBV co-infection in northern Thailand. Asian Pac J Trop Dis. 2016;6(3):174-8.

48. Apidechkul T. Epidemiology of the hill tribe HIV/AIDS populations, Thailand. J Med Assoc Thail. 2016;99(6):703-8.

49. Jobayer M, Chowdhury SS, Shamsuzzaman SM, Islam MS. Prevalence of hepatitis B virus, hepatitis C virus, and HIV in overseas job seekers of Bagladesh with the possible routes of transmission. Mymensigngh Med J. 2016:25(3):530-5.

50. Bakarey AS, Akinboade IO, Aken'Ova YA. Transmission transmissible hepatitis $B$ virus markers of infection among sickle cell disease patients receiving care at a tertiary health facility in Ibadan, southwest Nigeria. J Immunoassay Immunochem. 2018:39(4):416-27.

51. Coughlin SS. Recall bias in epidemiological studies. J Cli Epidemiol. 1990; 43(1):87-91.

52. Belbasis $L$, Bellou V. Introduction to epidemiological studies. Methods Mol Biol. 1793;2018:1-6.

Ready to submit your research? Choose BMC and benefit from:

- fast, convenient online submission

- thorough peer review by experienced researchers in your field

- rapid publication on acceptance

- support for research data, including large and complex data types

- gold Open Access which fosters wider collaboration and increased citations

- maximum visibility for your research: over $100 \mathrm{M}$ website views per year

At $\mathrm{BMC}$, research is always in progress.

Learn more biomedcentral.com/submissions 